\title{
Forced expiratory indices in normal Libyan children aged 6-19 years
}

\author{
MOHAMMAD H SHAMSSAIN, JAMES THOMPSON, SIMON A OGSTON \\ From the Departments of Physiology and Community Medicine, University of Dundee
}

ABSTRACT Forced vital capacity (FVC) and forced expiratory volume in one second (FEV $)_{1}$ were measured in 796 Libyan children (386 boys and 410 girls) with ages ranging from 6 to 19 years. Values in girls were significantly less than those in boys after allowance had been made for age and height. FVC and FEV 1 correlated best with standing height but were also correlated with body weight. These results may be used as a source of standard values for Libyan children.

\section{Introduction}

Pulmonary function studies have been carried out on various populations to establish reference values and formulae from which normal values can be predicted according to age, sex, and standing height. These reference or normal values of respiratory function, which have been shown to depend on the ethnic and racial origin of the population, are used to identify abnormal values and hence the nature and the degree of functional abnormality.

The aim of this study was to present reference values of forced expiratory indices for Libyan children as these have not been described previously.

\section{Methods}

We selected non-smoking, healthy Libyan schoolchildren from various schools at Benghazi on the Mediterranean coast. We excluded children with a history of respiratory disease and rejected 55 children because they were unable to perform spirometric tests adequately. All the children were of the same ethnic origin and there was little variation in socioeconomic conditions in the population studied.

Forced expirations were measured with an expired gas bellows spirometer (Vitalograph Inc), with the subject standing and wearing a noseclip. Only the recordings that satisfied the criteria of Segall and Butterworth ${ }^{1}$ for maximal mid expiratory flow time were considered, and the highest of three measurements was selected. The following

Address for reprint requests: Dr M H Shamssain, Department of Physiology, Dundee University, Dundee DDI 4HN.

Accepted 2 March 1988 measurements were obtained from the tracing: forced vital capacity (FVC), forced expiratory volume in one second $\left(F E V_{1}\right)$, forced expiratory ratio $\left(F E V_{1} /\right.$ FVC $\times 100$ ), forced expiratory flow between the first 200 and $1200 \mathrm{ml}$ of the FVC $\left(\mathrm{FEF}_{200-1200}\right)$, and forced mid expiratory flow between $25 \%$ and $75 \%$ of the FVC (FMF). All volumes were converted to body temperature and pressure saturated volumes (BTPS). The same equipment and observer were used for all subjects and the recordings were made between $8.00 \mathrm{am}$ and $1.00 \mathrm{pm}$ over eight months. The mean (SD) ambient temperature in the thermostatically controlled laboratory was $20^{\circ} \mathrm{C}\left(1^{\circ} \mathrm{C}\right)$.

Age was calculated to the nearest 6 months from the birth certificates (table 1). Standing height was measured to $0.1 \mathrm{~cm}$ with a portable stadiometer (Holtain Ltd) and body weight to $0.1 \mathrm{~kg}$ with portable field survey scales (CMS Weighing Equipment Ltd).

\section{DATA ANALYSIS}

The data were initially plotted graphically on box plots and scatter plots with percentile curves estimated by linear regression. Correlation coefficients were calculated for the various physical and lung function measurements. Multiple regression analysis was used to assess the simultaneous effects of age, height, weight, and sex on log transformed lung function measures. Other models were tried by progressively extending the number of variables to include: $(a)$ all four explanatory variables; $(b)$ interaction terms between sex and height, age, and weight, to allow for the possibility that these three covariates might ciffer in their effect between boys and girls; (c) separate height terms for children above and below 13 years, to allow for possible changes in the influence of height on lung function in children of different ages. Calculations 
Table 1 Age distribution of the children in the study

\begin{tabular}{|c|c|c|c|c|c|c|c|c|c|c|c|c|c|c|}
\hline Age (y) & 6 & 7 & 8 & 9 & 10 & 11 & 12 & 13 & 14 & 15 & 16 & 17 & 18 & 19 \\
\hline $\begin{array}{l}\text { Boys (n) } \\
\text { Girls (n) }\end{array}$ & $\begin{array}{l}30 \\
23\end{array}$ & $\begin{array}{l}26 \\
25\end{array}$ & $\begin{array}{l}22 \\
28\end{array}$ & $\begin{array}{l}21 \\
27\end{array}$ & $\begin{array}{l}19 \\
23\end{array}$ & $\begin{array}{l}22 \\
25\end{array}$ & $\begin{array}{l}37 \\
23\end{array}$ & $\begin{array}{l}28 \\
23\end{array}$ & $\begin{array}{l}20 \\
22\end{array}$ & $\begin{array}{l}31 \\
26\end{array}$ & $\begin{array}{l}41 \\
39\end{array}$ & $\begin{array}{l}32 \\
44\end{array}$ & $\begin{array}{l}28 \\
52\end{array}$ & $\begin{array}{l}29 \\
30\end{array}$ \\
\hline
\end{tabular}

were performed with the Statgraphics computer program $^{2}$ and GLIM. ${ }^{3}$

\section{Results}

The correlation coefficients between physical and lung function measurements are shown in table $2 . \mathrm{FEV}_{1}$ and FVC were highly correlated with each other and both were highly correlated with age, standing height, and body weight. FEF and FMF showed moderate correlations with these variables whereas $\mathrm{FEV}, \% \mathrm{VC}$ was independent.

Table 3 shows the values of the coefficient of determination $\left(R^{2}\right)$ obtained with several simple and multiple regression models. Of the explanatory variables investigated, height showed the strongest correlations with all the lung function indices. Sex differences were small in relation to the variation explained by height. After age and height have been allowed for, the difference between boys and girls was still evident. Inclusion of age as an additional variable in the multiple regression equations after height and sex had been fitted gave a further small increase in the coefficient of determination.

The more complicated models (i-iii under "Data analysis" above) did not change the coefficients of determination appreciably. A simple regression model using height as the predictor variable appears to give a reasonable description of the observed data for most of the measures. Figures 1 and 2 show selected estimated percentile curves based on height only. For

Table 2 Correlation matrix of physical and lung function measures for boys and girls

\begin{tabular}{|c|c|c|c|c|c|c|c|}
\hline & Age & Weight & Height & $F V C$ & $F E V_{1}$ & $F E F$ & $F M F$ \\
\hline $\begin{array}{l}\text { Age } \\
\text { Weight } \\
\text { Height } \\
\text { FVC } \\
\text { FEV, } \\
\text { FEF }\end{array}$ & 1 & $\begin{array}{l}0.818 \\
0.824 \\
1\end{array}$ & $\begin{array}{l}0.925 \\
0.877 \\
0.876 \\
0.844 \\
1\end{array}$ & $\begin{array}{l}0.906 \\
0.837 \\
0.880 \\
0.836 \\
0.924 \\
0.881 \\
1\end{array}$ & $\begin{array}{l}0.896 \\
0.823 \\
0.860 \\
0.816 \\
0.912 \\
0.862 \\
0.978 \\
0.945 \\
1\end{array}$ & $\begin{array}{l}0.630 \\
0.525 \\
0.550 \\
0.473 \\
0.612 \\
0.542 \\
0.650 \\
0.590 \\
0.685 \\
0.734 \\
1\end{array}$ & $\begin{array}{l}0.735 \\
0.658 \\
0.690 \\
0.602 \\
0.740 \\
0.670 \\
0.772 \\
0.702 \\
0.816 \\
0.827 \\
0.644 \\
0.731\end{array}$ \\
\hline
\end{tabular}

FVC - forced vital capacity; FEV $_{1}$-forced expiratory volume in one second; FEF-forced expiratory flow; FMF-forced mid expiratory flow. every centimetre increase in standing height FVC. increased $2.17 \%$ in boys and $2.42 \%$ in girls. FEV on $_{\overrightarrow{+}}$ the other hand increased $2.28 \%$ and $2.41 \%$ in boyso and girls respectively. A slightly improved prediction is possible for most of the indices if age is also included ${ }_{m}^{\times}$ in the multiple regression equation. Table 4 shows the coefficients resulting from multiple regression of $\log _{A}$ lung function on height, age, and sex. For example,, predicted $\log \mathrm{FVC}=-1.781+0.0148(\mathrm{HT})+\mathrm{O}$ $0.0405(\mathrm{AGE})-0.157$ (if SEX = female). The FEF and FMF data as well as enlarged versions of figures $1 \subseteq$ and 2 are available from the authors.

Lung function values increased progressively with ${ }_{\vec{\circ}}$ age in boys and girls. Being dependent on body size, $\mathscr{\infty}$ they levelled off in girls at the age of 15 years and in boys at the age of 18 years.

\section{Discussion}

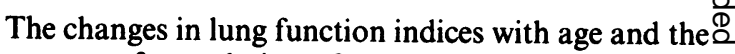
pattern of correlations found among our variables $\overrightarrow{\overrightarrow{0}}$ were broadly similar to those found by Dickman et al 3 in American children, ${ }^{4}$ by Sliman et al in Jordanian children, ${ }^{5}$ and by Deshpande $e t$ al in Indian children. ${ }^{6}$.

The Libyan children in our study had FVC and

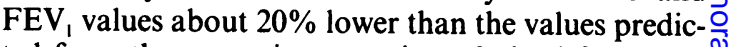
ted from the regression equations derived from Jordanian children. This may be due to the effect of $\frac{0}{3}$

Table 3 Coefficients of determination $\left(R^{2}\right)$ obtained in multiple regression analysis (percentages)

\begin{tabular}{|c|c|c|c|c|}
\hline \multirow{2}{*}{$\begin{array}{l}\text { Explanatory } \\
\text { variables }\end{array}$} & \multicolumn{4}{|c|}{ Dependent variable (log transformed) } \\
\hline & $F V C$ & $F E V_{1}$ & $F E F$ & $F M F$ \\
\hline $\begin{array}{l}\text { Age } \\
\text { HT } \\
\text { WT } \\
\text { Sex } \\
\text { Sex, age } \\
\text { Sex, height } \\
\text { Sex, weight } \\
\text { Sex, height, age, weight } \\
\text { Sex, height, age } \\
\text { Sex, weight, age } \\
\text { Sex, height, weight } \\
\text { Sex (height, age, weight) } \\
\text { Sex, height, age, weight, } \\
\text { HtA† }\end{array}$ & $\begin{array}{r}72 \cdot 5 \\
80 \cdot 6 \\
65 \cdot 1 \\
2 \cdot 9 \\
78 \cdot 1 \\
82 \cdot 0 \\
68 \cdot 5 \\
82 \cdot 7 \\
84 \cdot 7 \\
81 \cdot 0 \\
84 \cdot 9 \\
85 \cdot 3 \\
84 \cdot 9\end{array}$ & $\begin{array}{r}72 \cdot 2 \\
79 \cdot 0 \\
63 \cdot 5 \\
2 \cdot 6 \\
77 \cdot 2 \\
80 \cdot 2 \\
66 \cdot 9 \\
80 \cdot 9 \\
83 \cdot 2 \\
79 \cdot 8 \\
83 \cdot 4 \\
83 \cdot 8 \\
83 \cdot 4\end{array}$ & $\begin{array}{r}44 \cdot 0 \\
50 \cdot 9 \\
36 \cdot 1 \\
2 \cdot 1 \\
49 \cdot 8 \\
52 \cdot 2 \\
39 \cdot 2 \\
52 \cdot 5 \\
55 \cdot 3 \\
51 \cdot 5 \\
55 \cdot 3 \\
56 \cdot 2 \\
55 \cdot 3\end{array}$ & $\begin{array}{r}51 \cdot 7 \\
54 \cdot 8 \\
43 \cdot 7 \\
1 \cdot 1 \\
54 \cdot 2 \\
55 \cdot 1 \\
44 \cdot 9 \\
55 \cdot 4 \\
57 \cdot 7 \\
55 \cdot 5 \\
57 \cdot 8 \\
58 \cdot 3 \\
58 \cdot 0\end{array}$ \\
\hline
\end{tabular}

* Fits separate height, age, weight terms for each sex.

†Fits sex, height, age, weight plus a separate height term for age $>13$ years ( $\mathrm{HtA})$.

Abbreviations as in table 2. 
Forced expiratory indices in normal Libyan children aged 6-19 years

FVC

(I)

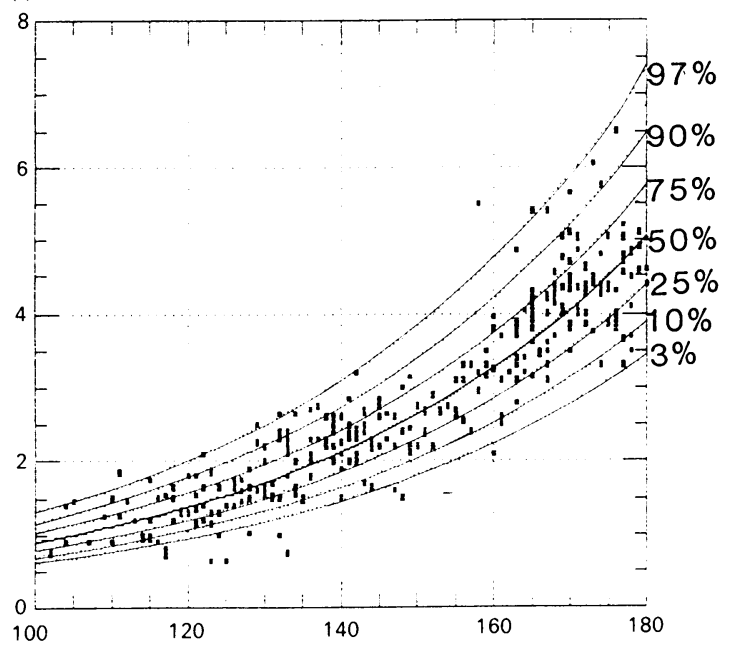

(a) HEIGHT(BOYS) $(\mathrm{cm})$

FVC

(1)

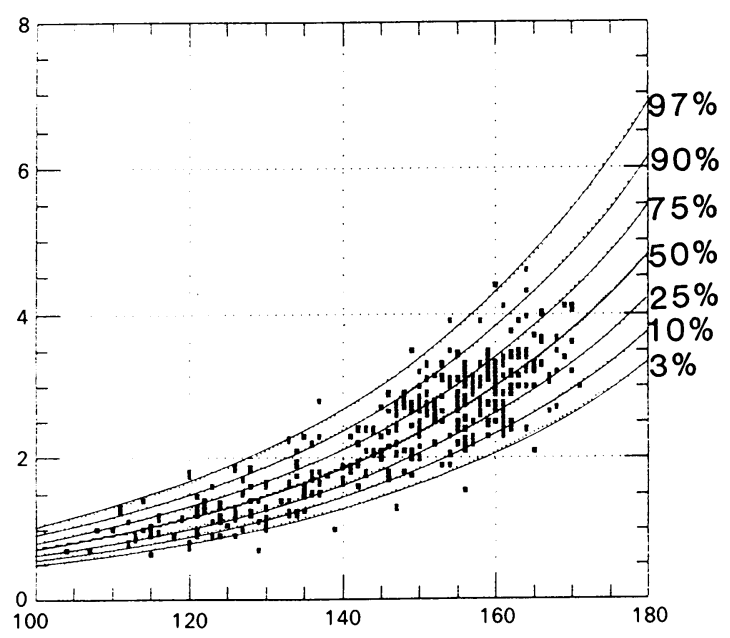

(b)
FEV,

(I)

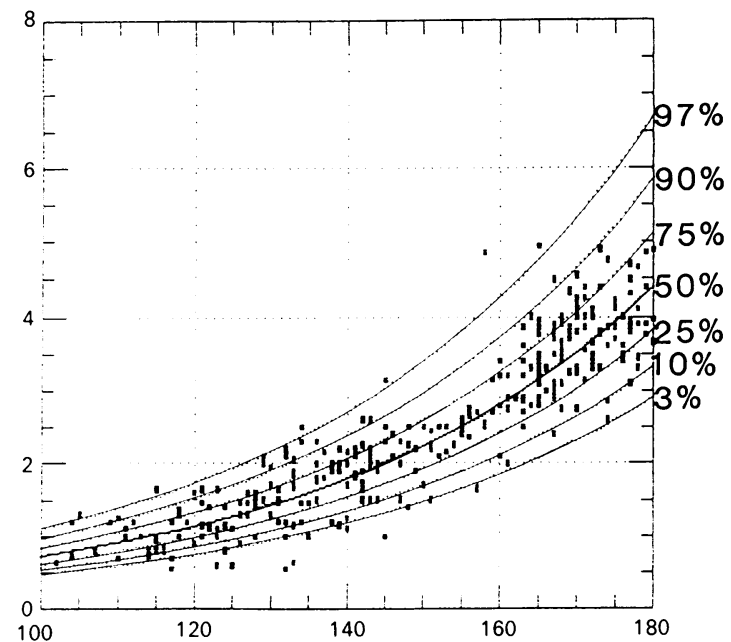

(a)

HEIGHT(BOYS)(cm)

FEV

(I)

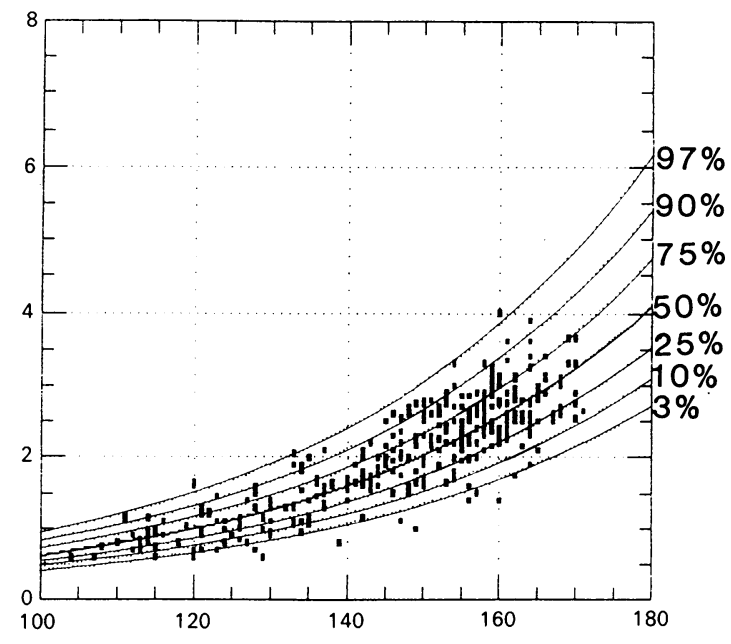

(b)
Fig 1 Percentile curves of forced vital capacity (FVC) plotted against standing height $(\mathrm{Ht}, \mathrm{cm}):($ a $)$ boys (log $F V C=0.021 \mathrm{Ht}-2 \cdot 257, r=0.919, \mathrm{SEE}=0.00052) ;(b)$ girls $(\log F V C=0 \cdot 023 \mathrm{Ht}-2 \cdot 693, r=0 \cdot 894$, $S E E=0.00064$ ). 
Table 4 Multiple regression coefficients in equations using height, age, and sex as explanatory variables

\begin{tabular}{|c|c|c|c|c|c|}
\hline \multirow[b]{2}{*}{$\begin{array}{l}\text { Dependent } \\
\text { variable }\end{array}$} & \multirow[b]{2}{*}{ Constant } & \multicolumn{4}{|c|}{ Independent variables } \\
\hline & & $\begin{array}{l}\text { Height } \\
(\mathrm{cm})\end{array}$ & Age (y) & $\begin{array}{l}\text { Sex } \\
(M=0, F=1)\end{array}$ & Sy.x \\
\hline $\begin{array}{l}\text { FVC } \\
\text { FEV, } \\
\text { FEF } \\
\text { FMF }\end{array}$ & $\begin{array}{l}-1.781 \\
-1.961 \\
-2.280 \\
-1.803\end{array}$ & $\begin{array}{l}0.0148^{* * *} \\
0.0146^{* * *} \\
0.0185^{* * *} \\
0.0150^{* * *}\end{array}$ & $\begin{array}{l}0.0405^{* * *} \\
0.0449^{* * *} \\
0.0513^{* * *} \\
0.0382^{* * *}\end{array}$ & $\begin{array}{l}-0.157^{* * *} \\
-0.153^{* * *} \\
-0.218^{* * *} \\
-0.115^{* * *}\end{array}$ & $\begin{array}{l}0 \cdot 181 \\
0 \cdot 201 \\
0.431 \\
0.380\end{array}$ \\
\hline
\end{tabular}

$* * * \mathrm{p}<0.001$.

Abbreviations as in table 2.

altitude since the Jordanian children were from Amman ( 774 metres above sea level) and the Libyan children were living at sea level. The rate of increase in FVC with height in adolescent Libyan boys was almost the same as that found in adolescent American boys studied by Dickman $(90 \mathrm{ml} / \mathrm{cm} \text { standing height })^{4}$ yet the rate in adolescent Libyan girls $(45 \mathrm{ml} / \mathrm{cm})$ was less than that found in adolescent American girls $(58.6 \mathrm{ml} / \mathrm{cm})$. Weight played a smaller part in determining lung function than in the Jordanian study, ${ }^{5}$ most of the variation in our data being explicable by age, sex and height. Adding body mass index (weight divided by height squared) instead of weight to our multiple regression equation made no difference to the coefficient of determination. Some studies ${ }^{57}$ have used logarithmic transformations of some of the explanatory variables (height, age) but this did not improve the fit in our study.

We did not record the pubertal status of the children so our results are useful for cross sectional rather than longitudinal comparisons. More detailed account of age, particularly during adolescence, would have to be taken to make longitudinal predictions.

There were few girls over $170 \mathrm{~cm}$ in height and few of either sex less than $110 \mathrm{~cm}$, so the percentile graphs in these ranges (figs 1 and 2) can not be regarded as reliable.
Our results provide a source of standard values for $\stackrel{\vec{F}}{\stackrel{\vec{S}}{*}}$ forced expiratory indices for Libyan children. We haveo no reason to believe that Benghazi children differ from 음 Libyan children in other parts of the country. Studies $\frac{\bar{m}}{\bar{D}}$ in other areas would, however, be useful to show $\varnothing$ whether they are representative of Libyan schoolchildren generally.

We thank the Dean of the Faculty of Medicine, Arab $\overrightarrow{\vec{\omega}}$ Medical University, Benghazi, for providing the $\stackrel{\odot}{\circ}$ facilities for this investigation; Professor C Florey $\vec{x}$ (Department of Community Medicine, Ninewells $\vec{c}$ Medical School, University of Dundee) for revising $\omega$ the manuscript; the headmasters and headmistresses -1 of various schools in Benghazi for arranging the visits; and Mrs M S Elramli, Mr R Elmugassbi, and Mr A윽 Eligwari for their technical help.

\section{References}

1 Segall JJ, Butterworth BA. The mid-expiratory flow time. Br J Dis Chest 1968;62:139-46.

2 Statistical Graphic Corporation. "Statgraphics" statistical graphic system. Rockville, Maryland: STSC Inç (2115 East Jefferson Street, Rockville, Maryland 20852), 1986.

3 Baker RJ, Nelder JA. The GLIM system, Release 3. Generalised linear interactive modelling. Oxford: $\odot$ Numerical Algorithms Group, 1978.

4 Dickman HL, Schmidth CD, Gardener RM. Spirometric 3 standard for normal children and adolescents. Am Rev? Respir Dis 1971;104:680-7.

5 Sliman NA, Dajani BM, Shubair KS. Pulmonary function in normal Jordanian children. Thorax 1982;37:854-7.

6 Deshpande JN, Dahat HB, Shirole CD, Pande AH. Pulmonary functions and their correlation with anthropometric parameters in rural children. Indian $J$ Ped 1983;50:375-8.

7 Dockery DW, Berkley CS, Ware JH, Speizer FE, Ferris BG. Distribution of forced vital capacity and forced? expiratory volume in one second in children 6 to $11>$ years of age. Am Rev Respir Dis 1983;128:405-12. 